
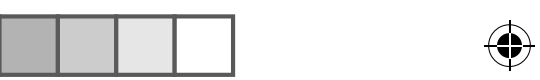

\title{
A SOBREPOSICCÃO LEGISLATIVA NO PLANO DIRETOR DE GOIÂNIA/2007: MEIO AMBIENTE, URBANISMO E AGRARIEDADE
}

THE LEGISLATIVE OVERVIEW AT THE GOIÂNIA / 2007 DIRECTORATE PLAN: ENVIRONMENT, URBANISM AND AGRARITY

Tamiris Melo Pereira ${ }^{1}$

\section{RESUMO}

A Região Norte de Goiânia vem passando por uma reorganização espacial que se expressa na dinâmica das relações econômicas, sociais, urbanísticas, ambientais e agrárias, fato esse que expõe a existência de uma problematicidade na aplicabilidade da legislação ambiental, agrária e urbana na chamada Região de Fronteiras (delimitadas nesse artigo pela Região Norte e pela Área $\mathrm{N}$ ), também emersa em um sistema regido por interesses políticos, econômicos e institucionais em constante interação e disputa hegemônica. Diante disso, o objetivo desse Artigo é compreender como se equaciona a sobreposição da legislação urbana, agrária e ambiental na produção da super-exploração do

1 Advogada, professora, Mestre em Direito Agrário pelo Programa de Pós-Graduação da Universidade Federal de Goiás, Bolsista Eiffel em M2 (PRO) Direito Ambiental, urbanismo e desenvolvimento sustentável em Limoges/França e Bacharel em Direito pela Pontifícia Universidade Católica de Goiás. CV: http://lattes.cnpq.br/6622003797279480. E-mail: tmp.dir@hotmail.com 
espaço da Região Norte de Goiânia e da Área N a partir da análise do Plano Diretor/2007. E para a compreensão dessa conjuntura de sobreposição legislativa são indispensáveis os estudo da coesão dinâmica, das duas principais leis relacionadas ao planejamento urbanístico no Brasil, primeiro o Estatuto da Cidade e, depois, os Planos Diretores, ambas sob o apoio analítico da política urbana e, por fim, a análise das alterações/inclusões de quatro artigos do Plano Diretor/2007 pela Lei complementar n. 246/2013: os artigos 110, 110-A, 116-A e 116-B que convalidam tal reorganização espacial.

Palavras chave: Região de Fronteiras. Legislação. Agrário. Ambiental. Urbanismo. Plano Diretor de Goiânia.

\section{ABSTRACT}

The Northern Region of Goiânia has undergone a spatial reorganization that expresses itself in the dynamics of economic, social, urban, environmental, and agrarian relations, a fact that exposes the existence of a problematic in the applicability of environmental, agrarian and urban legislation in the Borders (delimited in this article by the North Region and Area N), also emerged in a system governed by political, economic and institutional interests in constant interaction and hegemonic dispute. Therefore, the objective of this article is to understand how the overlap of urban, agrarian and environmental legislation in the production of space exploration in the Northern Region of Goiânia and Area N is analyzed, based on the analysis of the 2007 Master Plan. And in order to understand this conjuncture of legislative overlap, it is indispensable to study the dynamic cohesion, the two main laws related to urban planning in Brazil, first the City Statute, and then the Executive Plans, both under the analytical support of urban policy and, finally, the analysis of the changes / inclusions of four Articles of the Master Plan / 2007 by the complementary Law $n$. 246/2013: Articles 110, 110-A, 116-A and 116-B which validate such spatial reorganization.

Keywords: Border Region. Legislation. Agrarian. Environmental. Urbanism. Master Plan of Goiânia. 


\section{INTRODUÇÃO}

Antes de a Região Norte ser vista como a nova promessa do avanço empreendedorista de Goiânia, ela era considerada periferia e última opção, senão a única, para a consolidação habitacional de pessoas expulsas de outras Regiões goianas tomadas pelo primeiro avanço do capital na cidade ${ }^{2}$. Isso, porque no Norte goianiense havia extrema dificuldade de consolidação habitacional devido às características territoriais naturais, o que não atraia os investimentos públicos-privados, então, a Região Norte sobrava aos imigrantes e a seus loteamentos ilegais. Por isso, tal Região era inicialmente composta por fazendas/chácaras, zonas de matas fechadas ou loteamentos urbanos ilegais, as chamadas invasões.

Todavia, na atualidade está ocorrendo uma reestruturação territorial da denominada Região de Fronteiras do Norte goianiense e da Área N. Salienta-se que tal reestruturação envolve diversas conexões entre setores variados, como o econômico, imobiliário, o âmbito privado, estatal, social e outros.

Tendo em vista o exposto, nesse artigo a análise/estudo dessa reestruturação perpassará, especificamente, pela influência da legislação na construção do território. Assim, a análise ocorrerá em torno da observação de como a sobreposição da legislação através das modificações do Plano Diretor de Goiânia de 2007 ocorre na Região de Fronteiras do Norte goianiense e, em vista disso, viabiliza a atual reestruturação territorial para o empreendedorismo, ao mesmo tempo em que deixa de lado questões como meio ambiente e bem estar social na cidade.

\section{O REGIME JURÍDICO URBANO ENTRE NORMAS AMBIENTAIS E AGRÁRIAS}

O urbanismo não é um fenômeno exclusivo da atualidade, mesmo que o surgimento do termo urbanismo ${ }^{3}$ seja relativamente re-

2 Foram denominadas no transcorrer desse artigo de imigrantes as pessoas expulsas de outras Regiões goianas tomadas pelo primeiro avanço do capital na cidade.

3 Segundo G. Bardet este termo (urbanismo) surgiu pela primeira vez em 1910. No entanto, conforme BENEVOLO (1971) pode-se dizer que o urbanismo moderno nasceu 
cente, uma vez que as regras urbanísticas já existiam desde as cidades antigas e medievais. Por conseguinte, a evolução da cidade está para o urbanismo como a evolução do urbanismo está para a progressão da cidade.

Na esfera do Direito, Hely Lopes Meirelles (p.523 apud SILVA, 2015, p. 31) define o urbanismo como "o conjunto de medidas estatais destinadas a organizar os espaços habitáveis, de modo a propiciar melhores condições de vida ao homem na comunidade".

Assim, enfatiza-se que o urbanismo contemporâneo é resultado da urbanização ${ }^{4}$ e da urbanificação ${ }^{5}$, que leva em conta as conexões de um fenômeno urbano corporativo, caótico e em redes, portanto, parte-se de uma visão globalizada do mundo.

De todos esses conceitos depreende-se que a segmentação e o individualismo próprios do método cartesiano é inábil para abarcar o estudo do complexo fenômeno urbano nas suas múltiplas relações da atualidade, por isso, a necessidade de uma análise interdisciplinar ${ }^{6}$ do urbanismo.

Essa interdisciplinaridade do Direito Urbanístico brasileiro é denominada de coesão dinâmica. Isso porque, como afirma Pierandrea Mazzoni (apud SILVA, 2015, p. 31), "a norma urbanística é, por sua na-

até mesmo antes de se utilizar este termo, isto é, entre 1830 e 1850 (ABIKO; ALMEIDA; BARREIROS, 1995, p.39).

4 Emprega-se o termo urbanização para designar o processo pelo qual a população urbana cresce em proporção superior à população rural (SILVA, 2015, p. 27).

5 É o processo deliberado de correção da urbanização, consistente na renovação urbana, que é reurbanização, ou na criação artificial de núcleos urbanos. Salienta-se que a solução desses problemas ocorre pela intervenção do Poder Público, que procura criar novas formas urbanas (SILVA, 2015, p. 27).

6 A distinção entre as categorias interdisciplinaridade e transdisciplinaridade não será relevada nesse artigo, pelo fato de essas merecerem um estudo mais completo e complexo, além de ainda não haver consenso doutrinário a respeito, nem precisão terminológica entre elas. Aqui, ter-se-á por interdisciplinar a simplicidade do significado: interação entre duas ou mais disciplinas. Porém, deve-se advertir que estas categorias não se confundem com o conhecimento multidisciplinar, esta sim, caracterizada pela ausência de troca ou fusão de métodos e estratégias de cognição, ou seja, recorrese as informações de várias matérias para estudar um determinado elemento, sem a preocupação de interligar as disciplinas entre si. 
tureza, uma disciplina, um modo, um método de transformação da realidade, de superposição daquilo que será a realidade do futuro àquilo que é a realidade atual".

E ainda, se agrega ao cunho da coesão dinâmica (interdisciplinaridade) o fato de a legislação urbanística ainda não ter adquirido unidade substancial, uma sistematização legislativa, ou seja, as normas encontram-se dispersas em diversas instituições ${ }^{7}$, que são ligadas apenas por guardarem em comum entre si uma conexão em função ao objeto regulado.

Tendo em vista tal característica, se assinalará a seguir primeiro a coesão dinâmica que há entre as normas urbanísticas e ambientais, e depois entre as normas agrárias e urbanísticas.

Quanto a primeira, o artigo 225, que tutela o meio ambiente na Constituição Federal de 1988-CF/88, afirma que "todos tem direito ao meio ambiente ecologicamente equilibrado [...]", assim, o Direito Ambiental e Urbanístico tem um objeto de estudo em comum: as cidades (espaço urbano), que no Direito Ambiental, é nomeado como meio ambiente artificial.

Além do meio ambiente natural e cultural, existe o artificial, integrado pelos bens fruto da intervenção humana, que não formam o patrimônio cultural. É matéria comum entre o Direito Ambiental e o Urbanístico, sendo a cidade o exemplo de patrimônio ambiental artificial dos mais relevantes, com as normas gerais da Política de Desenvolvimento Urbano fixadas no artigo 182, da Constituição de 1988, regulamentada pelo Estatuto da Cidade (Lei 10.257/2001), visando ordenar o pleno desenvolvimento das funções sociais da cidade e garantir o bem-estar da população (AMADO, 2014, p. 510).

7 Diante dessa dispersão legislativa, ainda é cedo para falar em autonomia do direito urbanístico, dado que só recentemente suas normas começaram a desenvolver em torno de um objeto especifico "[...] talvez seja por isso que, os franceses especialmente, não falem em direito urbanístico, mas em direito do urbanismo, denotando com isso, que não se trata de um ramo do Direito, mas de aspectos jurídicos, ou regime jurídico, ou disciplina jurídica, do urbanismo" (SILVA, 2015, p.43). 
O ambiental e o urbano convivem hoje principalmente devido ao surgimento do chamado urbanismo sustentável, que aparece como instrumento e parceiro das políticas ambientalistas e urbanas. Desse modo, a cidade não pode estar dissociada da análise das condições ambientais, isto posto, nada mais correto do que aplicar os artigos 225 e 182 da CF/88 em consonância.

Já no que diz respeito à coesão dinâmica entre o Direito Agrário e o Urbanístico, faz-se necessário trazer o conceito do primeiro, que conforme Paulo Torminn Borges (1987, p.17) é "o conjunto sistemático de normas jurídicas que visam disciplinar as relações do homem com a terra, tendo em vista o progresso social e econômico do rurícola e o enriquecimento da comunidade".

Quando Torminn fala da relação do homem com a terra, soluciona questão polêmica no que diz respeito à dicotomia ${ }^{8}$ do que seja propriedade urbana e rural, já que segundo ele o homem pode relacionar-se com a terra independente de sua localização (cidade ou campo). Portanto, uma propriedade rural pode estar dentro da cidade também.

Assim, atenta-se para o fato de a legislação ambiental falar em meio ambiente, da urbanística em cidades e da agrária em terras, mas, no fim, o que se tem é a utilização de termos diferentes para a existência dos diversos espaços de convivência social, exemplo disso é a ocorrência das Regiões de Fronteiras ${ }^{9}$ em Goiânia.

8 A dicotomia surge porque o Artigo $4^{\circ}$ do Estatuto da Terra divide os prédios em rurais ou rústicos e urbanos, que se diferenciam pela localização. Depois, o Estatuto da Terra, graças a inclusão do princípio da Função social da propriedade na constituição brasileira, estabeleceu como critério diferenciador entre imóvel rural e urbano a destinação, ou seja, a terra seria usada para que fins, quais atividades, independentemente da localização geográfica (cidade ou campo). Mas, o Código Tributário Nacional de 1966 adotou o critério da localização para fins de cobrança do ITR (Imposto Territorial Rural), que se mantém até hoje. Desse modo, salienta-se que considera a localização para a questão do ITR, via lei n. 9393 de 1996, mas para a diferenciação do imóvel rural e urbano considera a destinação, via artigo 4 da Lei n. 8629 de 1993 (MARQUES, 2011, p.30-31).

9 Fala-se em Região de Fronteiras, pois foi visualizada a existência de algumas áreas de transição e de mútuo convívio no Norte goianiense, onde o meio agrário (onde se encontram pastagens, antigas fazendas), ambiental (onde há valiosa riqueza hídrica, já que abrange a Bacia do Rio Meia Ponte e suas microbacias, dentre essas, a microbacia do Córrego Caveiras, além das diversas Áreas de Preservação Permanente) e o urbano coexistirão em uma mesma área da cidade, mas que, ao mesmo tempo, estarão em 


\section{ESTATUTO DA CIDADE, PLANOS DIRETORES E POLÍTICA URBANA COMO INSTITUIÇÕES JURÍDICAS}

As duas principais leis relacionadas ao planejamento urbanístico no Brasil são: primeiro o Estatuto da Cidade e depois, os Planos Diretores, ambas sob o esteio da política urbana.

Dentro da temática urbanística, há quatro termos com diferenças sutis: política urbana, planejamento urbanístico, plano urbanístico e Plano Diretor. Eles (os termos) respeitam uma gradação (do amplo para o específico) na qual a Política Urbana abrange todos, até chegar ao específico/local, o Plano Diretor.

Entende-se por Política Urbana o conjunto de diretrizes, posturas e atitudes que nortearão o processo de planejamento urbano. Ela está no capítulo de política urbana da Constituição Federal de 1988 (artigos 182 e 183) e é regulada pelo Estatuto da Cidade (Lei n. 10.257 de 10 de julho de 2001).

Tal política urbana expressa na CF/88 é nova e resulta da luta por um urbano reformulado que advém de um processo de reforma jurídica e principiológica que tem sido promovida no Brasil há aproximadamente três décadas.

Estes princípios foram articulados a partir do Movimento pela Reforma Urbana em resposta às tensões criadas ao longo do século $X X$, que resultaram num espaço urbano marcado pela segregação espacial, ambiental, social e econômica cuja conseqüência mais visível é a violência urbana. O sucesso desta pactuação resultou na inclusão da política urbana no texto constitucional e na aprovação do Estatuto das Cidades (BONDUKI, 2007, p. 215-219 apud RODOVALHO, 2012, p.24).

constantes alteridades e disputas de sobreposições hegemônicas, sejam elas sob o aspecto territorial ou legislativo. 
[...] uma nova ordem jurídico-urbanística, articulada e compreensiva - sofisticada mesmo- se constituiu no Brasil nas últimas três décadas, inclusive com o reconhecimento constitucional do direito urbanístico como ramo autônomo de direito público que tem como princípios paradigmáticos as "funções socioambientais da propriedade e da cidade" e a "gestão democrática das cidades". Diretamente comprometida com a agenda sociopolítica da reforma urbana - e etapa crucial na construção nacional e internacional do tão clamado direito à cidade -, a ordem jurídica brasileira já mudou significativa e estruturalmente (FERNANDES, 2016, p.24).

É nesse contexto, que se destaca o surgimento do Estatuto da Cidade (Lei n. 10.257/2001) que traz o direito à habitação digna, à universalização de acesso ao saneamento básico, ao transporte público de qualidade, a sustentabilidade urbana, à gestão democrática da cidade, a função social da propriedade urbana e outras diretrizes gerais inclusas em seu artigo $2^{\circ}$.

Por isso, cumpre ao Estatuto da Cidade:

[...] as funções supraindicadas de uma lei geral, na medida em que institui princípios de direito urbanístico, disciplina diversas figuras e institutos do direito urbanístico, fornece um instrumental a ser utilizado na ordenação dos espaços urbanos, com observância da proteção ambiental, e a busca de solução para problemas sociais graves, como a moradia, o saneamento, que o caos urbano faz incidir, de modo contundente, sobre as camadas carentes da população. Seu Capítulo I estabelece as diretrizes gerais da política urbana, que tem por objetivo ordenar as funções sociais da cidade e da propriedade urbana, nos termos do caput do art. 182 da CF; o Capítulo II indica os instrumentos da política urbana, tais os planos nacionais, regionais e estaduais de ordenação do território e de desenvolvimento urbano e social; o planejamento as regiões metropolitanas, aglomerações urbanas e microrregiões; o planejamento municipal (plano diretor; zoneamento etc.); institutos tributários e financeiros; institutos jurídicos e políticos; o parcelamento, edificação ou utilização compulsória; o IPTU progressivo no tempo; desapropriação com 
pagamento em títulos; usucapião especial de imóvel urbano; direito de superfície; o direito de preempção; a outorga onerosa do direito de construir; as operações urbanas consorciadas, a transferência do direito de construir; o Estudo de Impacto de Vizinhança (SILVA, p. 67-68, 2015).

Porém, é relevante observar, como diz Edésio Fernandes (2016, p.30) que "se leis ruins podem dificultar a implementação plena de políticas públicas progressistas [...], boas leis por si só não mudam realidades urbanas e sociais", por isso, é necessário que, para além da reforma jurídica urbana constante na CF/88 e no Estatuto das Cidades, haja planejamento urbano por parte do Poder Público num sistema articulado de gestão urbana.

Dessa forma, a Política Urbana e o Planejamento ${ }^{10}$ se complementam, ou seja, ao elaborar a nova política urbana e incluí-la na Constituição, entendeu-se que a primeira somente poderia se concretizar por meio de um planejamento urbanístico democrático ${ }^{11}$ realizado com base no consentimento popular (artigo $2^{\circ}$, inciso II e artigo 43 do Estatuto da Cidade), no qual o povo deverá participar trazendo legitimidade ao planejamento. Sobre isso, sintetiza Lubomir Ficinski (apud SILVA, 2015, p.108):

O novo tipo de planejamento - uma nova fase- será de conteúdo humano e democrático. É um completo engano pensar que a Democracia atrapalha o planejamento, mesmo porque, se esta antinomia fosse contrária, o planejamento é uma forma de organizar a Democracia e de exprimi-la. O que devemos dizer, de forma clara e tranquila, é que este tipo de planejamento toma o partido da maioria da população da cidade e a defende- aliás, por isso ele é democrático. Sendo democrático, ele se coloca contra pressões ilegítimas ou erradas

10 O planejamento significa, em geral, "um processo técnico instrumentado para transformar a realidade existente no sentido e objetivos previamente estabelecidos" (SILVA, 2015, p.87).

11 "É válido destacar que democracia não se mede por quantidade de eventos e de participantes! Democracia se mede, entre outras variáveis, pela equalização das condições de debate e pelo respeito ao contraditório" (PEDROSO, 2015, p.136). 
em relação ao crescimento e à direção da cidade. Mas ainda assim busca contê-las e orientá-las adequadamente - e não eliminá-las de vez, pois é um planejamento que reconhece algumas circunstancias básicas da vida urbana. Acrescenta, depois, que é preciso estar ouvindo constantemente as gentes, para determinar o que elas querem e o que sentem. $E$ conclui que "a democracia no planejamento apresenta uma vantagem inigualável: ao mesmo tempo em que o progresso é menos rápido, é um pouco mais lento, permite também que os erros cometidos sejam menos duradouros", e que "outro resultado, nunca negligenciável no planejamento democrático, é que a discussão pública gera o apoio- se o plano é bom, evidentemente- e esse apoio público garante sua execução".

Em contrapartida, a diferença entre planejamento urbanístico e plano urbanístico consiste no fato de o primeiro ser um processo de caráter amplo, - não tão amplo quanto a Política Urbana-, e que antecede o plano, sendo propostas técnicas/administrativas que ainda não têm dimensão jurídica. Já o último (o plano), "é o meio pelo qual se instrumentaliza o processo de planejamento" e que "materializa as determinações e os objetivos previstos nele (o planejamento)" (SILVA, 2015, p. 88-92).

o plano urbanístico não constitui simples conjunto de relatórios, mapas e plantas técnicas, configurando um acontecer unicamente técnico. O plano urbanístico adquire, ele próprio, por contaminação necessariamente dialética, as características de um procedimento jurídico dinâmico, ao mesmo tempo normativo e ativo, no sentido de que os anteprojetos elaborados por técnicos e especialistas adquirem a categoria de diretrizes para a política do solo e sua edificação, ao mesmo tempo em que, em seus desdobramentos, se manifesta como conjunto de atos e fundamentos para a produção de atos de atuação urbanística concreta.

[...]

Os planos urbanísticos constituem conjuntos de normas e atos operativos que caracterizam aquele princípio de coesão dinâmica ou coesão dialética que dá a essência das normas urbanísti- 
cas, consoante expulsemos noutro lugar. Baldado será, portanto, qualquer intento de compreender a estrutura normativa dos planos urbanísticos com base na concepção clássica que procura conhecer as normas jurídicas em sua estrutura interna, isolando uma das outras; essa concepção estático-atomístico-abstrata não pode penetrar o sentido das normas do plano, cujos efeitos saem, como feixes, do conjunto, para modelar o futuro colimado, mediante transformações do existente (SILVA, 2015, p.95).

Assim, "o processo de planejamento urbanístico adquire sentido jurídico quando se traduz em planos urbanísticos" (SILVA, 2015, p.92). Mas, nem por isso, falar em Plano Diretor seja o mesmo que dizer plano urbanístico, pois o primeiro remete ao documento legislativo elaborado exclusivamente pelo Município, portanto, ele (o Plano Diretor) trata de temáticas relativas aos aspectos locais, enquanto o segundo assume um caráter mais amplo, que pode ser feito também pela União e pelos Estados, porém, todos eles são leis.

Desse modo, infere-se que existem diversos Planos urbanísticos, à vista disso, com base na Constituição de 1988, SILVA (2015, p.104) declara que já se pode falar em efetivar no Brasil um sistema de planos estruturais:

Um sistema de planejamento urbanístico estrutural comporta a construção hierárquica de planos de ordenação territorial com amplitudes diversas, indo dos arcabouços maiores dos planos nacionais e macrorregionais até os mais limitados dos planos microrregionais e locais, de tal sorte que os nacionais estabeleçam as diretrizes e objetivos gerais do desenvolvimento da rede urbana no território nacional em função do plano nacional de desenvolvimento econômico-social; os macrorregionais desceriam aos aspectos mais particularizados das regiões em função do planejamento econômico-social regional; os planos estaduais e os microrregionais dentro de cada Estado, observadas aquelas diretrizes e objetivos, seriam planos de coordenação urbanística; e, finalmente, cada Município faria seu plano urbanístico (plano diretor), segundo suas necessidades e conveniências, respeitados as diretrizes e objetivos econômicos e sociais fixados nos planos de nível superior (SILVA, 2015, p.103). 
Mas, mesmo que os planos existam em âmbito Federal, Estadual e Municipal, ou seja, sejam estruturais, este artigo irá ater-se a análise particular de um dos instrumentos ${ }^{12}$ da Política Urbana, qual seja: o Plano Diretor. Já que essa é a lei que tutela a Região aqui estudada, além de ser o principal instrumento de política e de expansão urbana, de acordo com os artigos $182, \S^{\circ}$ da CF/88 e 40 do Estatuto da Cidade.

Segundo o Artigo 41 do Estatuto da Cidade, o Plano Diretor é obrigatório para cidades com mais de 20.000 habitantes, integrantes de regiões metropolitanas, aglomeração urbana e de áreas de interesse turístico, onde o Poder Público Municipal pretenda utilizar os instrumentos do parcelamento, edificação e utilização compulsórios ou inseridos na área de influência de empreendimentos ou atividades com significativo impacto ambiental de âmbito regional. A partir do Plano Diretor são organizadas as leis suplementares, específicas: Lei do Parcelamento e Uso do Solo, Lei de Edificações, Lei de Zoneamento, Legislação Ambiental e Sanitária.

Ele (o Plano Diretor) é elaborado pelo Executivo Municipal, por intermédio dos órgãos da Prefeitura, e contém disposições de aspecto técnico que se apresentam sob a forma gráfica, compreendendo relatório, mapas e quadros que consubstanciam o retrato da situação existente e as projeções da situação futura, transformada. Porém, a formulação desse documento é uma tarefa técnica multidisciplinar, pois, embora predominem os aspectos técnicos, revela-se, ainda, como um procedimento também jurídico, dadas as exigências legais que impõem a ele a observância de determinadas regras de conduta (SILVA, 2015, p. 142).

Tendo em vista essas características, o Plano Diretor é considerado um instrumento técnico-jurídico. Isto posto, José Afonso da Silva (2015, p. 142) inspirado nos 10 passos de elaboração do Plano Diretor de Jorge Wilheim estipula as seguintes etapas de produção de um Plano Diretor:

a) Estudos preliminares: que avaliam de forma sumária a situação e os problemas de desenvolvimento do Município e es-

12 Os instrumentos urbanísticos estão estipulados no Artigo $4^{\circ}$ do Estatuto da Cidade. 
tabelecem as características e o nível de profundidade dos estudos subsequentes;

b) Diagnóstico: que pesquisa e analisa em profundidade os problemas de desenvolvimento selecionados na etapa anterior, identifica as variáveis que devem ser consideradas para as soluções desses problemas e prevê suas perspectivas de evolução. Par dar resposta a essas indagações, o diagnostico compreenderá duas partes: a primeira consiste numa análise retrospectiva da situação existente, em que se procurará identificar os principais problemas e suas causas; a segunda configurará uma análise projetiva, em que serão salientados os meios necessários a utilizar para a solução daqueles problemas verificados, de acordo com as diretrizes gerais estabelecidas e com vistas ao atendimento das necessidades constatadas (SILVA, 2015, p.143);

c) Plano de diretrizes: que estabelece uma política para as soluções dos problemas escolhidos e fixa objetivos e diretrizes da organização territorial e

d) Instrumentação do plano: que compreende a elaboração dos instrumentos de atuação, de acordo com as diretrizes estabelecidas, e identifica as medidas capazes de atingir os objetivos escolhidos.

Dentre os instrumentos que incorporaram a elaboração do Plano Diretor encontra-se o projeto de lei a ser submetido à Câmara Municipal $^{13}$. O conteúdo do projeto de lei do futuro Plano Diretor corresponde ao conteúdo do próprio plano, ou seja, o documento nascido das etapas de produção acima citadas.

No processo jurídico de elaboração de um Plano Diretor, merece especial atenção os capítulos III e IV do Estatuto da Cidade, pois o

13 A iniciativa dessa lei pertence ao Prefeito e o processo de elaboração dela segue as regras do processo legislativo estabelecido na Lei Orgânica de cada Município, das Resoluções do Conselho das Cidades e do Estatuto da Cidade. 
primeiro trata especificamente do Plano Diretor, enquanto o segundo trata da gestão democrática das cidades.

Logo que o Projeto é apresentado à Câmara, com todos os documentos do plano, o Presidente desta o remeterá às comissões competentes para estudo e parecer, podendo haver, inclusive, emendas ${ }^{14}$.

O projeto é considerado aprovado pelo voto qualificado de dois terços dos membros da Câmara Municipal, mas esse número varia, a depender do que a Lei Orgânica de cada Município estatui. Depois disso, o projeto torna-se lei, e então recebe o nome de Plano Diretor. Além de destacar a importância do Plano Diretor como instrumento técnico - jurídico, evidencia-se que sua eficácia por si só não basta, essa lei precisa ser efetiva. $\mathrm{Na}$ atualidade das cidades, tem-se na efetividade dos Planos Diretores uma grande pedra de toque.

A lei só tem valor se tiver aplicabilidade, ou seja, deve ser eficaz e efetiva. Efetividade é diferente de eficácia. Nas palavras de Silva, P. (2001) eficácia da lei é a exigência da lei após sua promulgação, seja em relação ao tempo de sua obrigatoriedade, seja em relação ao território que passa a vigorar e tem aplicação. Assim diz-se eficácia da lei no tempo para indicar o período ou momento em que passa a ser aplicada obrigatoriamente para todos os atos ou fatos por ela regulados, e eficácia no espaço para significar o local ou limite territoriais em que pode exercer a sua influência. Efetividade por sua vez significa o que está em vigência, está sendo cumprido, ou seja, está realizando seus próprios efeitos. No Direito Administrativo opõe-se à inatividade, interinidade, qualidade da norma permanente que está sendo exercida, que surte os efeitos desejados pela regra (PASQUALETTO; RODOVALHO, 2012, p.45 grifo da autora).

PASQUALETTO e RODOVALHO articulam algumas possíveis razões que explicam a não efetividade dos Planos Diretores:

14 A execução material do plano diretor efetiva-se através da aplicação da respectiva lei, o que pode exigir a expedição de leis especiais, de regulamentos previstos ou necessários, bem como de planos executivos, planos especiais e planos parciais, nele exigidos. 
a) A mudança de governo com a chegada de um novo partido ao poder, pode significar o abandono do Plano Diretor elaborado pela gestão anterior, ou ainda, a mudança das gerências encarregadas de implantá-lo, pois são cargos de confiança, geralmente comissionados, e nem sempre ocupados por profissionais qualificados para a função (VILLAÇA, 2001 apud PASQUALETTO; RODOVALHO, 2012, p.43);

b) o caráter meramente teórico dos Planos, pois para Villaça os Planos Diretores elaborados no Brasil possuíam intuito mais teórico (ideológico) que prático [...] estes planos não passaram do discurso, não se constituíram em ações concretas do Estado (PASQUALETTO; RODOVALHO, 2012, p.43);

c) as alterações surgidas em função de legislações dissociadas dos objetivos e princípios do Plano, em que ao regulamentá-lo, o legislador faz outra interpretação das diretrizes propostas ou elabora leis extemporâneas cujas finalidades se opõem as diretrizes do Plano, ou ainda pela falta de regulamentação (RODOVALHO, 2012, p.54);

d) os empreendedores imobiliários pressionam o poder público a aprovar loteamentos na zona rural mesmo que o município disponha de áreas anteriormente parceladas e ainda não ocupadas e mesmo que não exista área urbana contígua ao parcelamento pretendido, por isso, é correto afirmar que a especulação imobiliária é uma das formas mais frequentes de desrespeito ao Plano Diretor. Assim como, a pressão exercida pelos movimentos populares, através de invasões de áreas privadas anteriormente parceladas. Em ambas as situações a gestão municipal fica refém de situações que impedem a aplicação dos projetos e ações previstos pelo Plano Diretor em detrimento de uma gestão emergencial e imediatista (RODOVALHO, 2012, p.64) e

e) em outras ocasiões é o próprio poder público o responsável pela falta de efetividade do Plano Diretor. A fim de solucionar a questão fundiária - principalmente as "invasões" - os governos lançaram mão de áreas situadas na zona rural do município para alocar a população de baixa renda, pois estas áreas são mais baratas, vez que se encontram fora da 
expansão urbana. Ou permitem (por omissão) a ocupação de zonas destinadas à proteção ambiental, como as margens de córregos e rios e encostas de morros - originando as favelas (RODOVALHO, 2012, p.66).

Portanto, várias prováveis causas concorrem para esta ineficácia, desde aspectos legais, econômicos, políticos e outros. Desse modo, mesmo com a importância do Plano Diretor para a administração da cidade, frequentemente, ele não é efetivado.

\section{REGIÃO NORTE DE GOIÂNIA E ÁREA N: A SOBREPOSIÇÃO LEGISLATIVA NO PLANO DIRETOR DE GOIÂNIA/2007}

Depois de todo aporte dado ao estudo da coesão dinâmica e da estrutura das normas urbanísticas, chega-se ao estudo central desse Artigo, no qual tem em destaque a realidade da Região de Fronteiras no Norte goianiense e da Área $\mathrm{N}^{15}$. Assim, a análise aqui presente vai muito além de visualizar a influência da lei na construção do território, ela (a análise) gira em torno de observar como a sobreposição da legislação ocorre na Região de Fronteiras do Norte goianiense e, portanto, como ela impacta o meio ambiente e subsequentemente a qualidade de vida dos moradores da Região estudada.

15 Em Goiânia, a Região de Fronteiras escolhida para estudo nesse artigo foi representada pela Região Norte de Goiânia. A Região Norte de Goiânia, segundo o Censo Demográfico de 2010, engloba os seguintes bairros: Candida de Moraes, Capuava, Urias Magalhães, Goiânia II, Santa Genoveva, Aeroporto Internacional, Jaó, Balneário Meia Ponte, Campus Universitário, Jardim Guanabara, Jardim São Judas Tadeu, Vila dos Sonhos, Manancial Campus, Rural (Setores 3,4 e 8) e Vila Rica. Entretanto, a análise não se restringe a esses bairros. O estudo também se concentrará na Região de Fronteiras localizada na Região Norte de Goiânia circundada pelas margens do Córrego Caveiras, no entorno do Shopping Passeio das Águas, da Avenida Perimentral Norte, da Avenida Goiás, áreas essas abrangidas, precisamente, pelos Setores Urias Magalhães, Finsocial, Vila Cristina e da Vila Industrial Pedro Abraão. Para tornar o estudo mais didático, tal entorno foi denominado de Área N pela autora. 
Para isso, faz se necessário tratar as alterações/inclusões de quatro artigos do Plano Diretor/2007 pela Lei complementar n. 246/2013 ${ }^{16}$, uma vez que eles são de extrema relevância para observar a reestruturação territorial sob a nova faceta empreendedora que mira na Região Norte de Goiânia e que, inclusive, vem sendo incentivada via Plano Diretor/2007. Os citados artigos são: 110, 110-A, 116-A e 116-B do Plano Diretor de Goiânia de 2007.

\subsection{ARTIGO 110 DO PLANO DIRETOR DE GOIÂNIA DE 2007}

O direcionamento do crescimento urbano para o Norte do Município de Goiânia, em grande parte, é provocado também pela atuação legislativa, via Plano Diretor/2007, pois mesmo que tal Região tenha relevante importância ambiental, o Plano Diretor a classificou como área de Adensamento Básico, ou seja, áreas que atualmente são pouco ocupadas, mas que se destinarão a incentivos ocupacionais futuros:

Art. 110 - Para efeito de dar tratamento urbanístico à Macrozona Construída ficam instituídas as seguintes unidades territoriais:

I - Áreas Adensáveis, para as quais serão incentivadas as maiores densidades habitacionais e de atividades econômicas, sustentadas pela rede viária e de transporte, subdividindo-se em duas naturezas:

a) aquelas áreas de maior adensamento, ao longo dos Eixos de Desenvolvimento Exclusivos e nas áreas caracterizadas como vazios urbanos;

b) aquelas áreas de médio adensamento, ao longo dos Eixos de Desenvolvimento Preferenciais.

16 Em 2007 foi lançado o novo Plano Diretor de Goiânia aprovado pela Lei complementar n. 171, ainda em vigência. Porém, tal Plano Diretor foi alterado pelo Projeto de lei complementar n. 28/20012, agora, já como Lei complementar n. 246/2013. 
II - Áreas de Desaceleração de Densidades, para as quais serão dirigidas ações de controle e redução do atual processo de densificação urbana;

III - Áreas de Adensamento Básico, correspondente às áreas de baixa densidade, para as quais será admitida a duplicação dos atuais padrões de densidade, visando a correlação das funções urbanas em menores distâncias e a otimização dos benefícios sociais instalados, estando sujeita ao controle de densidades resultante da relação do número de economias por fração ideal de terreno;

IV - Áreas de Restrição à Ocupação, para as quais serão estabelecidas normas de restrição parcial ou absoluta à ocupação urbana (grifo da autora).

Pela Figura 1 abaixo, se observa a sobreposição do crescimento de Goiânia, por três décadas, com as áreas de consolidação urbana definidas no Plano Diretor de 2007. Nela (a figura) identifica-se, segundo Nascimento e Oliveira (p. 163, 2015), a existência "de áreas definidas como de Adensamento Básico no norte, oeste e sudoeste do município que ainda não tinham sido ocupadas até o ano de 2010, indicando possíveis futuros vetores de crescimento" (grifo da autora). 
Figura 1: Sobreposição do crescimento urbano de Goiânia (1986/2010) com as áreas de consolidação urbana definidas pelo Plano Diretor de 2007

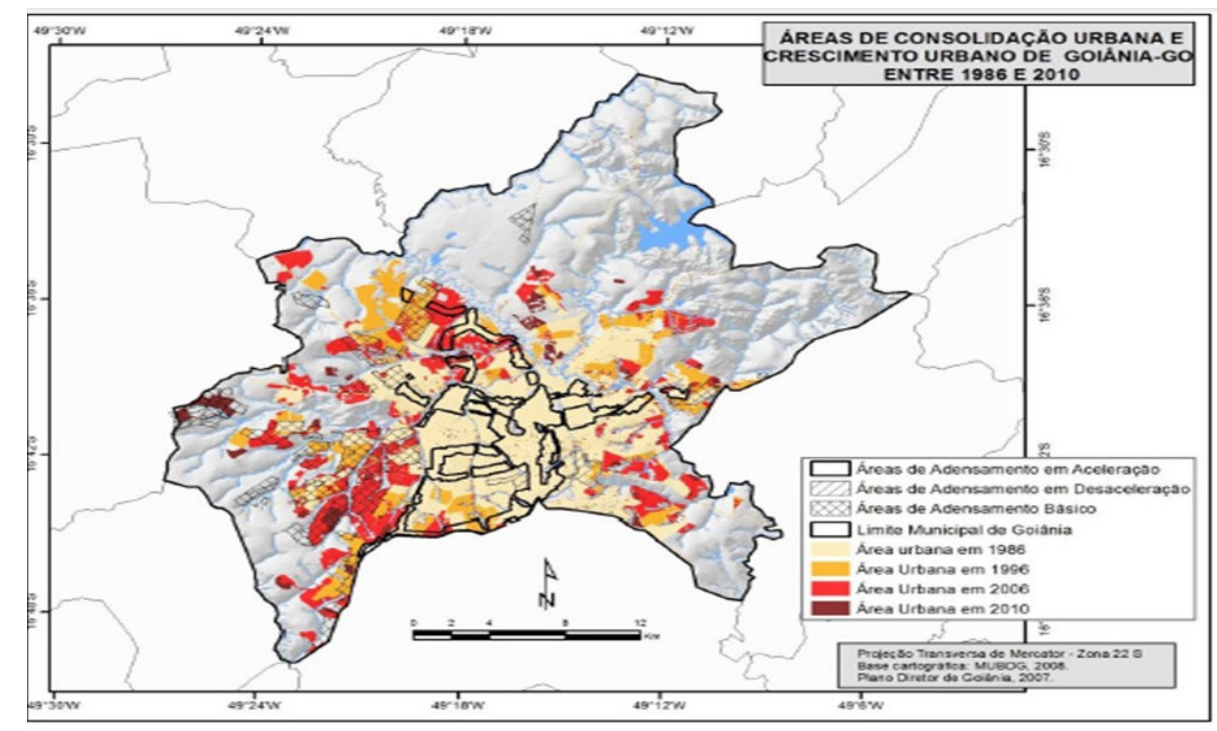

Fonte: NASCIMENTO; OLIVEIRA, p. 165, 2015

Em contrapartida à destinação da área do Norte goianiense como de adensamento básico estipulada no artigo 110 do Plano Diretor/2007 e visualizada na Figura 1, há na Carta de Risco de 1993, como áreas aptas à ocupação urbana, a porção centro-sul no mapa representado pela Figura 2 (em azul e rosa) e sudoeste (em bege e laranja), com indicação de adoção de medidas de contenção aos processos erosivos e de obras de drenagem urbana (NASCIMENTO; OLIVEIRA, 2015, p.155).

Desse modo, a Carta de Risco de 1993 (Figura 2) concebe como áreas impróprias à ocupação urbana as planícies, os terraços e os fundos de vale (em vermelho, marrom e verde claro, respectivamente) e toda a porção norte e nordeste do município (em amarelo e roxo), com a indicação da necessidade de destinação destas áreas à preservação ambiental e recarga de mananciais (NASCIMENTO; OLIVEIRA, 2015, p.155 grifo da autora). 
Figura 2: Carta de Risco do Município de Goiânia de 1993

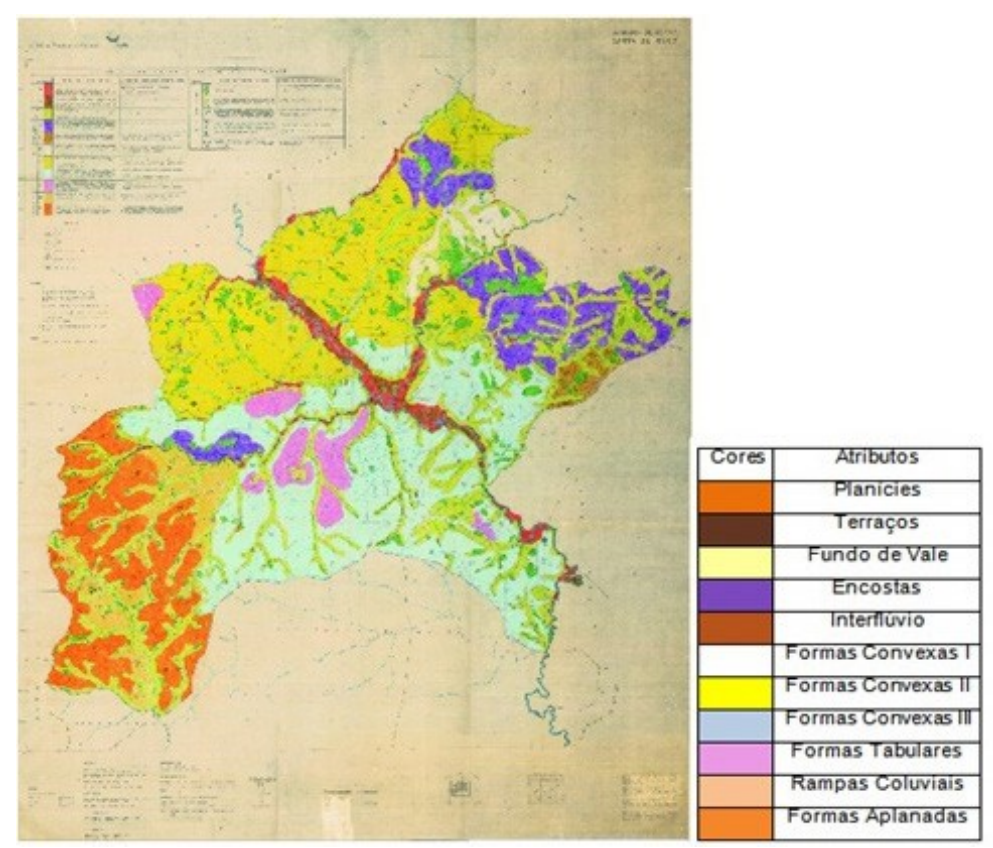

Fonte: Elaborada pela própria autora a partir da Carta de Riso de Goiânia de 1993

A mesma constatação de inadequação ao parcelamento urbano da Região Norte de Goiânia por causa de problemas geomorfológicos (matas e recursos hídricos) se repete na atual Carta de Risco de Goiânia, para a Área N, como observado na Figura 3:

Figura 3: Síntese dos Aspectos de Susceptibilidade ao Risco de ocupação da Microbacia do Córrego Caveiras (Área N)

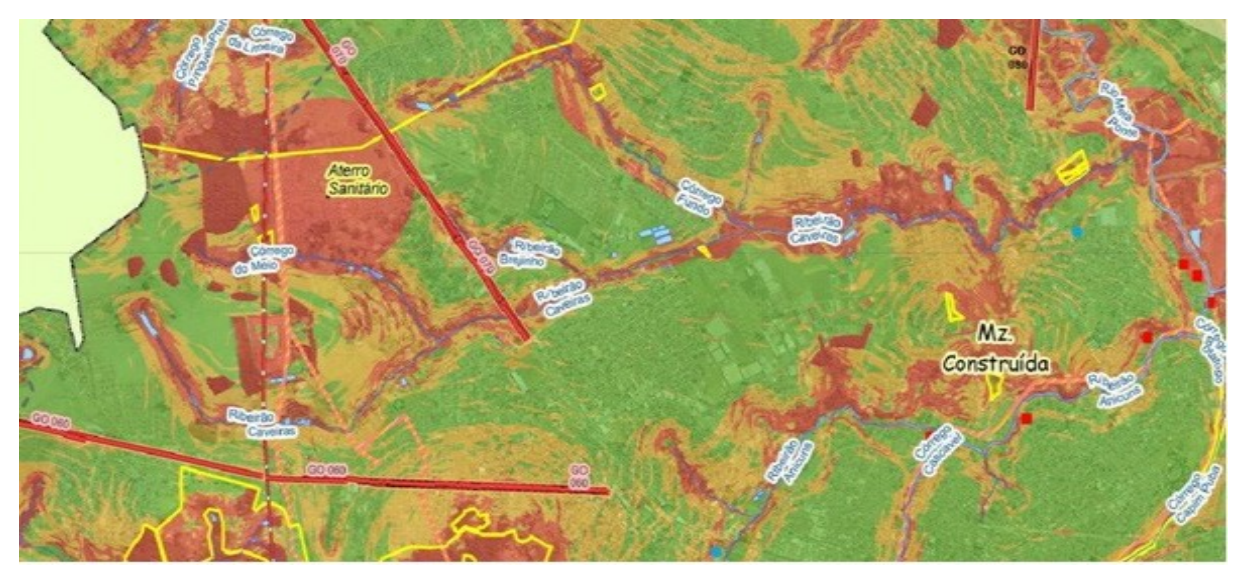

Fonte: Elaborada pela própria autora a partir da Carta de Risco de Goiânia, 2008 


\section{Tabela 1: Síntese dos Aspectos de Susceptibilidade ao Risco de ocupação da} Microbacia do Córrego Caveiras (Área N)

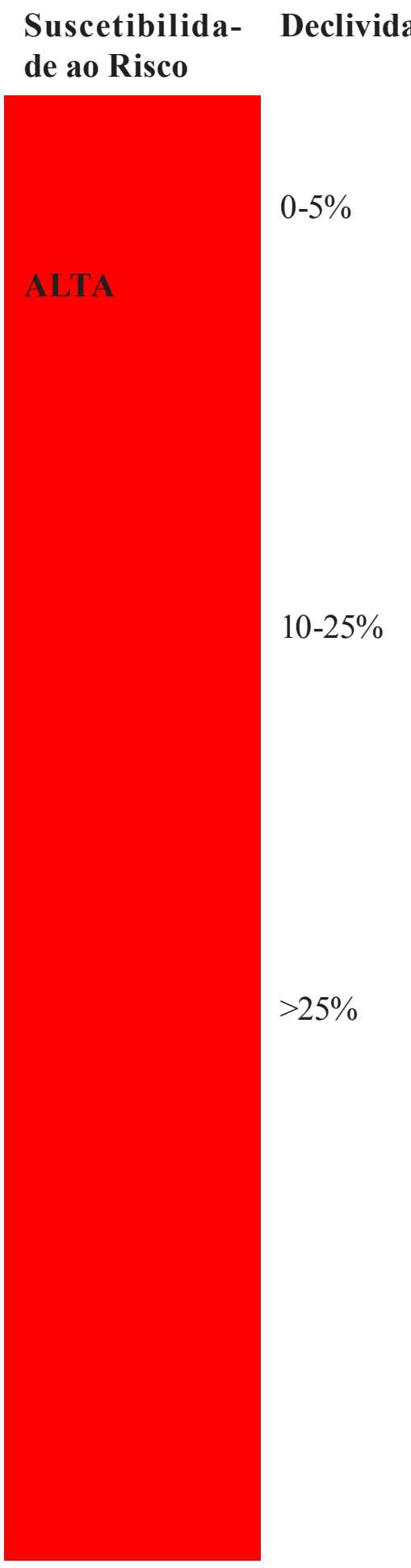

\section{Características Gerais}

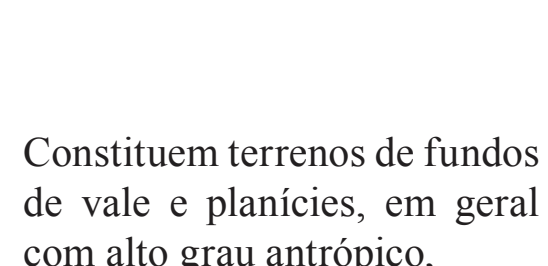

com áreas residuais preservadas.

Terrenos de fundo de vale, em geral com alto grau de degradação e ocupações diversas, com geração de processo erosivo por solapamento

Terrenos com encostas abruptas e convexas, observados nas regiões dos Córregos Lajeado/ Capoeirão, Ribeirão João Leite e Anicuns

\section{Aptidões}

Áreas impróprias à ocupação de qualquer natureza e indicadas a preservação e/ou recuperação

Áreas impróprias à ocupação de qualquer natureza e indicadas a preservação e/ou recuperação

Áreas impróprias à ocupação urbana, com riscos de escorregamentos de massa. Constituem áreas de recarga dos aquíferos superficiais e subterrâneos. Essa área pode ser destinada a agropecuária 


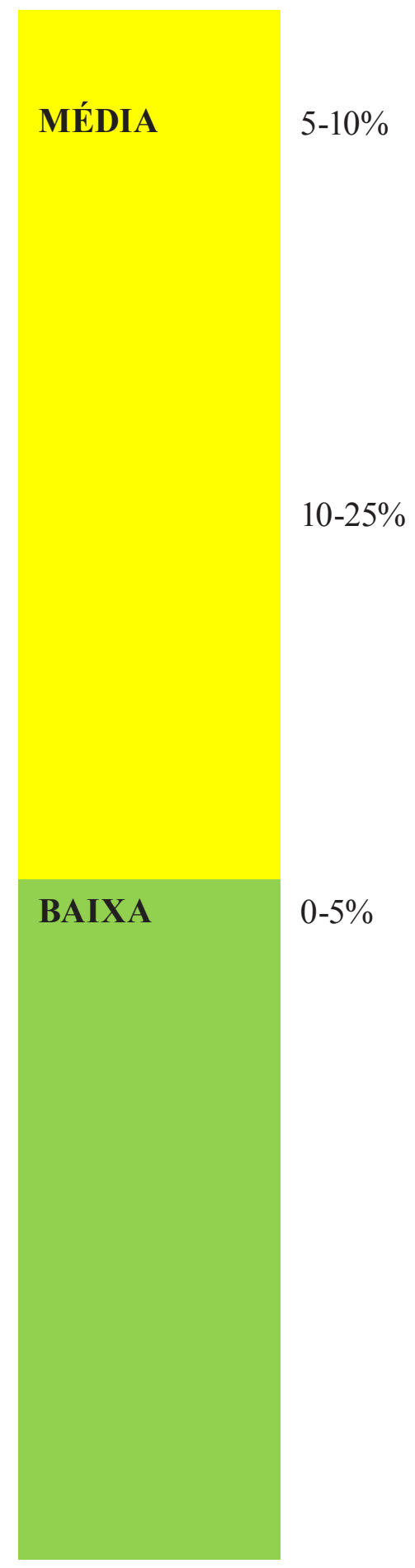

Terrenos com encostas suaves observados na região dos Córregos Cascavel, Macambira, Cavalo Morto, Taquaral, Salinas, Quebra-Anzol, Dourados e margem direita do curso do Ribeirão Anicuns, e Sistema Lajeado/Capoeirão

Áreas com declives variados observados na região dos córregos Cascavel, Macambira, Cavalo Morto, Taquaral, Salinas, Quebra-Anzol, Dourados, São Domingos e margem esquerda do curso do Ribeirão Anicuns, e Sistema Lajeado/ Capoeirão

Terrenos planos e suavemente inclinados com encostas suaves
Áreas próprias à ocupação urbana, porém com riscos de concentração de fluxos e geração de processos erosivos próximos aos canais de drenagem

Áreas que podem ser destinadas à ocupação urbana, porém com riscos de concentração de fluxos e geração de processos erosivos próximo aos canais de drenagem

Áreas próprias a ocupação urbana, porém com riscos de concentração de fluxo e geração de processo erosivo em áreas inclinadas desprovidas de vegetação

Fonte: Elaborada pela própria autora a partir da Carta de Risco de Goiânia, 2008.

Justapondo os dados da Figura 3 à análise descritiva da Tabela 1 observa-se a presença da alta suscetibilidade do risco de ocupação 
das margens do Córrego Caveiras (em vermelho na figura), regiões essas de concentração das Áreas de Preservação Permanente (APP) que, portanto, são impróprias a ocupação e que devem ser preservadas, conservadas e/ou revitalizadas.

Fora das proximidades das Áreas de Preservação Permanente (em vermelho na figura) predominam os terrenos planos próprios a ocupação urbana (em cor verde na figura), que representa o restante da Área $\mathrm{N}$. Porém, salienta-se que, mesmo nessas áreas propicias a construção urbana próximas de APP's, quando têm desrespeitados os limites ambientais para construção na APP, invadindo a zona vermelha, as áreas antes propicias a ocupação ficam expostas aos mais variados resultados e processos de degradação ambiental e social, como: enchentes, erosões, desmoronamentos, falta de saneamento básico, poluição e outros. Essa ação/reação trata de uma resposta natural, proveniente do desequilíbrio ecológico.

\subsection{ARTIGO 110-A DO PLANO DIRETOR DE GOIÂNIA DE 2007}

Com as alterações impostas pela Lei Complementar n. 246/2013 acrescentou-se ao Plano Diretor o artigo 110-A:

Art. 110-A - Para os vazios urbanos, não integrantes dos Eixos de Desenvolvimento, localizados na Macrozona Construída, admite-se a implantação de Áreas de Equipamentos Especiais de Caráter Regional compreendendo área, gleba ou quinhão com no mínimo 10.000,00 m² (dez mil metros quadrados), sem restrição à dimensão de testadas, com ou sem exigência de parcelamento prévio, admitindo-se a implantação dos seguintes usos ou atividades, mediante análise de equipe multidisciplinar do Órgão Municipal de Planejamento e Urbanismo ou seu sucedâneo legal (grifo da autora):
a) Esporte;
b) Lazer e cultura;
c) Saúde e assistência social;
d) Culto e educação; 

e) Serviços e de ordem pública;
f) Abastecimento;
g) Transporte;
h) Comunicação;
i) Natureza econômica diversa;
j) Natureza mista entre os anteriormente citados.

Parágrafo único- Excepcionalmente, os usos ou atividades implantados em áreas de equipamentos especiais de caráter regional, não sofrerão limitações quanto à altura máxima, respeitados os demais parâmetros urbanísticos estabelecidos nesta Lei

Nesse artigo destaca-se as palavras: vazios urbanos, eixos de desenvolvimento e Áreas de Equipamentos Especiais de Caráter Regional. A definição de vazios urbanos está no artigo $5^{\circ}$ da Lei Complementar n. 181/2008. Como já foi dito, a Região Norte se encontra em uma área em que predomina o Adensamento Básico, porém, na Região há também diversos vazios urbanos.

Quanto aos Eixos de Desenvolvimento, explicita o Plano Diretor, como é visualizado na Figura 4, que a Região Norte não se encontra em uma área de desenvolvimento, mas sim, em princípio de desenvolvimento, por isso, de adensamento básico e, então, sujeita aos incentivos de ocupação:

Figura 4: Desenvolvimento Econômico de Goiânia

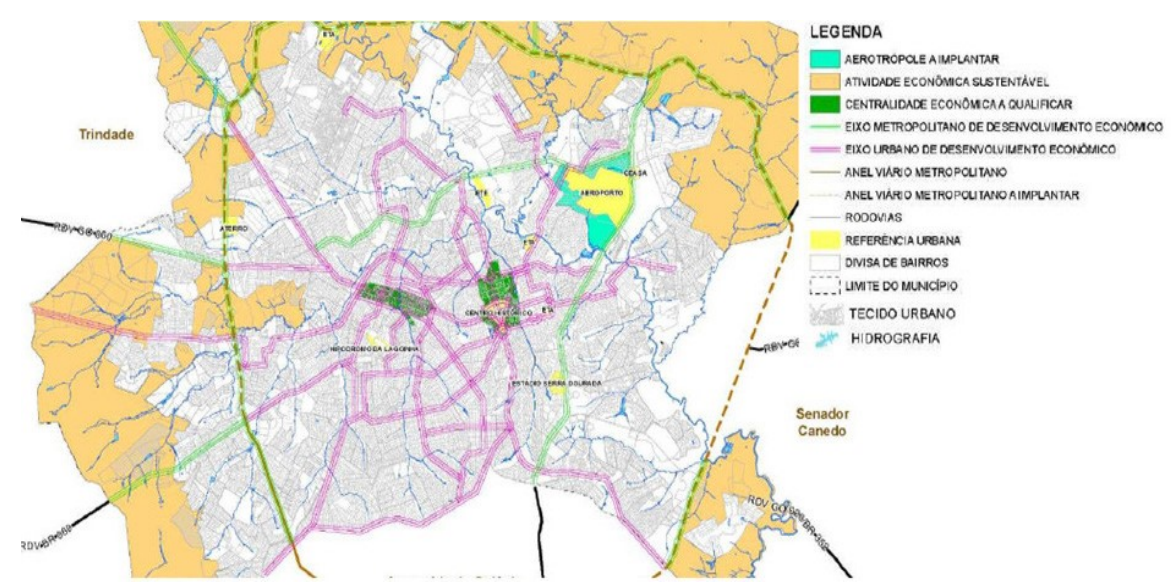

Fonte: Elaborada pela própria autora a partir do Plano Diretor de Goiânia de 2007 
Quanto as Áreas de Equipamentos Especiais de Caráter Regional, foi encontrado seu significado em explicação divulgada pelo Prefeito de Goiânia daquela época, Paulo Garcia, no Jornal Diário de Goiás, em matéria redigida pelo jornalista Altair Tavares. Tal matéria tinha o intuito de melhorar o entendimento das mudanças no Plano Diretor de Goiânia, por isso, ela trouxe como conteúdo o significado de cada alteração feita pela Lei Complementar n. 246. Segundo a matéria jornalística (TAVARES, 2013) o Artigo 110-A:

[...] é voltado para grandes equipamentos especiais de caráter regional, como hospital de urgência; ginásios de esporte; terminais de ônibus, metrô, Veículo Leve sobre Trilhos (VLT) ou qualquer meio de transporte a ser utilizado na capital; atividades de natureza econômica qualquer, inclusive mista entre os anteriormente citados, como empreendimentos que comportam em um só lugar: shopping, hospital, moradia e empresas que não produzem incomodidade. A adequação é voltada para a nova face da cidade que tem procurado, em empreendimentos multiuso e multifuncionais, respostas para que a questão da mobilidade, já que as pessoas poderão morar, trabalhar e consumir bens, serviços e cultura em um mesmo empreendimento. As construções podem ir além dos 63 mil metros quadrados permitidos hoje, sem limite de altura (grifo da autora).

Então, conclui-se e fica comprovado pelas Figuras que a Região Norte é impactada por esse artigo, já que tem áreas consideráveis de vazios urbanos, não integrantes dos Eixos de Desenvolvimento, e que está localizada na Macrozona Construída de Goiânia. Porém, ao comparar a localização dos diversos Vazios Urbanos com a Carta de Risco de 2008 do Município de Goiânia, conforme a Figura 5 abaixo faz, depreende-se e reitera-se a riqueza ambiental existente na $\mathrm{Re}$ gião Norte e o grande impacto que causarão a construção de mais e novos Equipamentos Especiais de Caráter Regional nos vazios urbanos dessa Região. 
Figura 5: Possíveis Vazios Urbanos e áreas de alta sensibilidade ambiental de acordo com a Carta de Risco de Goiânia de 2008

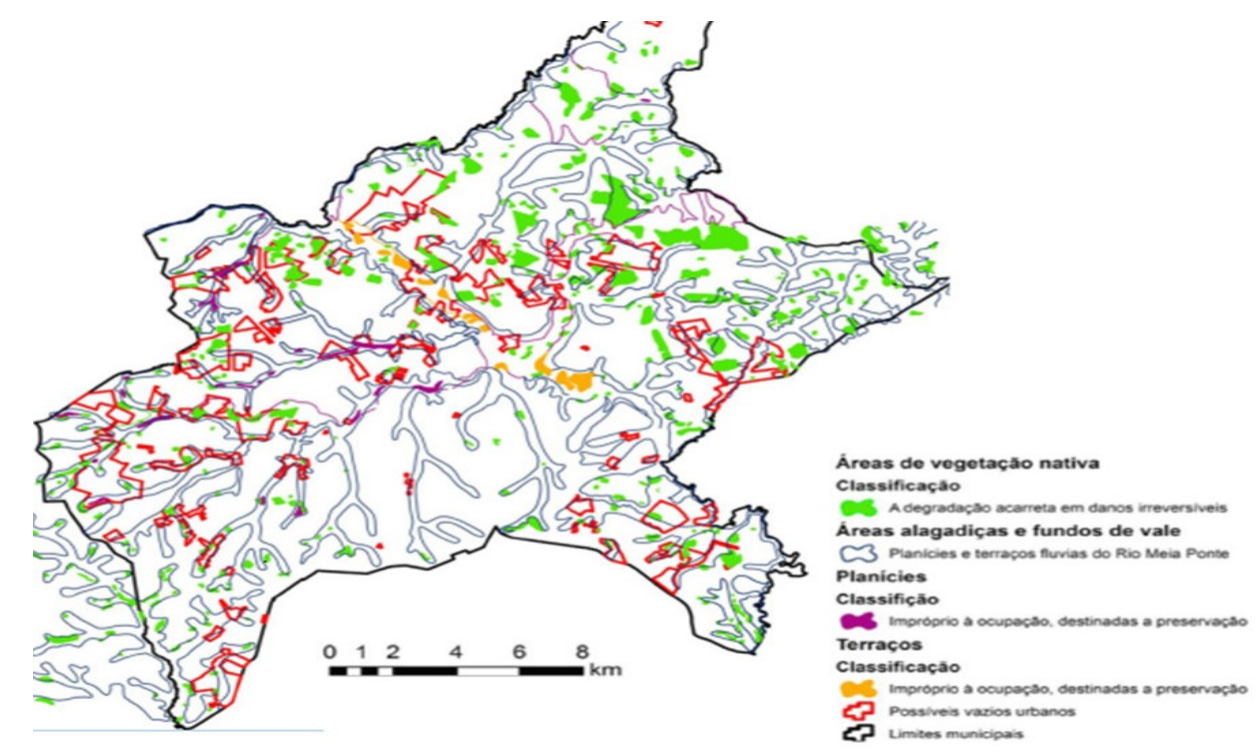

Fonte: Parecer Técnico sobre as Mudanças no Plano Diretor de Goiânia, 2013, p.18.

Para o Parecer Técnico sobre as Mudanças no Plano Diretor de Goiânia (2013, p.19) o artigo deve ser totalmente revisto devido aos seguintes motivos:

a) Necessidade de considerar o atendimento à Carta de Risco de Goiânia e demais documentos técnicos pertinentes, bem como estabelecer claramente o que será admitido;

b) Devem ser mencionados os parâmetros restritivos de construção para dimensão de testada, altura máxima de pé-direito, área máxima de área construída, etc;

c) Devem ser estabelecidos usos específicos e jamais utilizar termos tão abrangentes, tais como: "Natureza Econômica Diversa" e "Natureza Mista" e

d) por provocar o rompimento do "Modelo Espacial" da cidade, princípio básico definido no Plano Diretor. Deveriam ser realizados estudos de impacto no trânsito e nos transportes, que foram concebidos para o modelo existente, mas, que sequer foram implementados e já não comportam a situação atual. 
Então, conclui-se do estudo desse artigo, usando um linguajar informal: "tá liberado", para o Norte goianiense a construção de grandes empreendimentos, tais como alguns já foram concretizados: Hugo 2, Shopping Passeio das Águas, Hypermarcas S/A e outros que ainda virão.

\subsection{ARTIGO 116-A DO PLANO DIRETOR DE GOIÂNIA DE 2007}

É o artigo 116-A do Plano Diretor de Goiânia/2007:

Art. 116-A - Os imóveis localizados nas vias locais, coletoras e arteriais delimitadas na Figura 10 - Área de Influência das Vias Expressas constante desta Lei atenderão ao grau de incomodidade e porte máximos admitidos para as seguintes vias expressas que as influenciam:
a) Perimetral Norte;
b) Anel Viário;
c) GO - 010;
d) GO - 020;
e) GO - 040;
f) $\mathrm{GO}-060$;
g) $\mathrm{GO}$ - 070;
h) $\mathrm{GO}$ - 080;
i) $\mathrm{GO}-462$;
j) $B R-060$;
k) BR - 153.

Parágrafo único - Excepcionalmente, não sofrerão limitações quanto a altura máxima, respeitados os demais parâmetros urbanísticos estabelecidos nesta Lei, os galpões destinados a depósitos e atividades industriais, localizados nas faixas bilaterais das vias expressas listadas no caput do artigo.

Para entender esse artigo, antes deve-se compreender o que são vias locais, coletoras, arteriais e vias expressas, bem como, o que significa grau de incomodidade e empreendimento de impacto. A hie- 
rarquia da rede viária e o significado de cada uma das vias estão expressos no Artigo 22 do Plano Diretor de Goiânia/2007:

Art. 22 - A hierarquia da rede viária de Goiânia é composta por vias existentes e projetadas, classificadas em:

I - Vias Expressas;

II - Vias Arteriais;

III - Vias Coletoras;

IV - Vias Locais;

V - Vias de Pedestre;

VI-Ciclovias.

$\S 1^{\circ}$ Vias Expressas são vias de fluxo intenso de veículos que possuem interseções de nível e em nível, propiciando maiores velocidades e que cumprem, como principal função, as ligações entre regiões do Município e a articulação metropolitana ou regional, subdividindo-se nas seguintes categorias:

I-Vias Expressas de $1^{\text {a }}$ Categoria - são vias de fluxo intenso de veículos, possuindo apenas interseções de nível com acessos às atividades econômicas por meio das vias paralelas;

II - Vias Expressas de $2^{\text {a }}$ Categoria - são vias de fluxo intenso de veículos, possuindo interseções de nível e em nível;

III - Vias Expressas de $3^{\text {a }}$ Categoria - são vias de fluxo intenso de veículos, com muitas interseções em nível e com acesso às atividades econômicas, exceto no Anel Rodoviário Metropolitano que será por meio de vias paralelas excluindo o trecho, já implantado, entre o Município de Aparecida de Goiânia e a BR-060.

$\S 2^{\circ}$ Vias Arteriais são vias estruturadoras do tráfego urbano, atendendo a circulação geral urbana, com pista dupla, com canteiro central ou pista única, com sentido duplo de tráfego, subdividindo-se nas seguintes categorias:

I - Vias Arteriais de $1^{\text {a }}$ Categoria - são vias de grande fluxo de veículos e que recebem a maior parte do tráfego de passagem; II - Vias Arteriais de $2^{\text {a }}$ Categoria - são vias destinadas preferencialmente, ao tráfego de passagem, porém com menor intensidade do que as de $1^{\text {a }}$ Categoria.

$\S 3^{\circ}$ Vias Coletoras são vias que recebem o tráfego das vias locais e o direciona para as vias de categoria superior. 
§ $4^{\circ}$ Vias Locais são vias que promovem a distribuição do tráfego local e propiciam o acesso imediato aos lotes, sendo identificadas como vias verdes àquelas que têm a função de separar as Unidades de Proteção Integral das áreas parceladas e ocupadas.

$\S 5^{\circ}$ Vias de Pedestre são vias secundárias ou locais, não permitindo a circulação de nenhum tráfego motorizado, destinadas à circulação exclusiva de pedestres.

Já o grau de incomodidade remete ao quanto, numa classificação de 1 a 5, determinada atividade influencia o território. $O$ artigo 101 do Plano Diretor de Goiânia/2007 estabelece:

Art. 101 - Os controles da distribuição das atividades no território classificam-se nos seguintes graus:

I - atividades de grau de incomodidade 1 (um);

II - atividades de grau de incomodidade 2 (dois);

III - atividades de grau de incomodidade 3 (três);

IV - atividades de grau de incomodidade 4 (quatro);

V - atividades de grau de incomodidade 5 (cinco).

$\S 1^{\circ}$ Atividades de grau de incomodidade 1 (um), compreendem aquelas que não causam incômodo e nem impacto significativo ao ambiente, à estrutura e à infra-estrutura urbana.

$\S 2^{\circ}$ Atividades de grau de incomodidade 2 (dois), 3 (três) e 4 (quatro), compreendem aquelas que têm potencial de causar incômodo e impacto significativo ao ambiente, à estrutura e à infra-estrutura urbanas.

$\S 3^{\circ}$ Atividades de grau de incomodidade 5 (cinco), compreendem aquelas que, por suas características excepcionais, provocam maior grau de incômodo e impacto ao ambiente, à estrutura e à infra-estrutura urbana. 
Observa-se que, além do grau de incomodidade, a listagem do Anexo II da Lei n. 8.617/08 traz como observação se a atividade é ou não um potencial Empreendimento de Impacto. Entende-se por empreendimento de impacto:

Art. 94 do Plano Diretor de Goiânia/2007-Empreendimentos e atividades de impacto, são os macro-projetos, não residenciais, públicos ou privados, que, quando implantados, venham a sobrecarregar a infra-estrutura urbana ou, ainda, de repercussão ambiental significativa, provocando alterações nos padrões funcionais e urbanísticos ou ao espaço natural circundante, como:

I - Os empreendimentos com capacidade de reunião de mais de 600 (seiscentas) pessoas simultaneamente;

II - Os empreendimentos que ocupam uma ou mais de uma quadra ou quarteirão urbano com área igual ou superior a $5.000 \mathrm{~m}^{2}$ (cinco mil metros quadrados);

III - Os empreendimentos potencialmente poluidores, conforme grau de incomodidade previsto em legislação específica.

IV - VETADO.

$\S 1^{\circ}$ VETADO.

$\S 2^{\circ}$ Ficam excluídos das exigências previstas no caput deste artigo os templos religiosos.

De todas as vias citadas no artigo 116-A, três são fundamentais ao local de estudo desse artigo (Região Norte de Goiânia e Área N), são elas: Avenida Perimentral Norte, Avenida Goiás e Avenida Eurico Viana. Na Tabela 2 abaixo está à classificação, o grau de incomodidade e se é permitido ou não empreendimento de impacto nas vias eleitas: 
InSURgência: revista de direitos e movimentos sociais

Tabela 2: Classificação e observações das Avenidas Perimentral Norte, Eurico Viana, Goiás e locais.

\begin{tabular}{lc}
\hline Via & Perimentral Norte \\
Classificação & $\begin{array}{c}\text { Via Expressa de } 3^{a} \\
\text { categoria- Pista Dupla }\end{array}$ \\
Observações & $\begin{array}{l}\text { PERMITIDO TODOS } \\
\text { OS USOS, EXCETO: }\end{array}$
\end{tabular}

a) Aqueles que não atendem a legislação ambiental;

b) E o Grau de Incomodidade GI-5 para as Avenidas Rio Verde e Avenida T-63.

\section{PERMITIDO SOB} CONDIÇÕES:

a)Todos os usos considerados geradores de alto Grau de Incomodidade, art.95 Lei $n^{\circ}$ 171/2007, deverá apresentar para apreciação Estudo de Impacto de Vizinhança e Estudo de Impacto de Trânsito, conforme Lei Específica (Então são permitidas atividades de qualquer grau de incomodidade, inclusive os empreendimentos

de grande impacto, desde que observados

$$
\frac{\text { os requisitos do }}{\text { Artigo } 95 \text { do Plano }}
$$
Diretor/2007);

b) Para os Macroprojetos atender o estabelecido nos art. 94 a 97 Lei ${ }^{\circ}$ $171 / 2007$.

$\begin{array}{ccc}\begin{array}{c}\text { Avenida Eurico } \\ \text { Viana }\end{array} & \text { Avenida Goiás } & \text { Via Local } \\ \begin{array}{c}\text { Via Arterial de } 2^{a} \\ \text { categoria- Pista } \\ \text { Única }\end{array} & \begin{array}{c}\text { Via Arterial de 1 } \\ \text { categoria- Pista } \\ \text { Dupla }\end{array} & \text { Via Local } \\ \end{array}$

\section{PERMITIDO TODOS OS USOS, TODOS OS USOS, EXCETO: \\ EXCETO:}

a) Grau de Incomodidade Gl-4 e Gl-5.

\section{PERMITIDO SOB CONDIÇÕES:}

a) Todos os usos considerados geradores de alto Grau de Incomodidade, art.95, Lei n 171/2007, deverá apresentar para apreciação Estudo de Impacto de

Vizinhança e Estudo de Impacto de

Trânsito, conforme Lei Específica;

b) Para os Macroprojetos atender o estabelecido nos art. 94 a 97 Lei n $171 / 2007$.
Grau de Incomodidade Gl-5.

\section{PERMITIDO SOB CONDIÇÕES:}

a) Todos os usos considerados geradores de alto Grau de Incomodidade, art.95 Lei $\mathrm{n}^{\circ}$ 171/2007, deverá apresentar para apreciação Estudo de Impacto de Vizinhança e

Estudo de Impacto de Trânsito, conforme Lei Específica;

b) Para os Macroprojetos atender o estabelecido nos art. 94 a 97 da Lei $n^{\circ} 171 / 2007$.

\section{DE PISTA ÚNICA/ PERMITIDO TODOS OS USOS, EXCETO:}

Grau de Incomodidade $\mathrm{GI}-2$, GI-3, GI-4 e GI-5;

b) Atividade com área ocupada superior a $360 \mathrm{~m}^{2}$.

c)Empreendimentos e atividades definidos como Macro- projetos;

d)Templos

Religiosos com área ocupada pela Nave Superior a $450 \mathrm{~m}^{2}$.

e) Atividades de estacionamento (CNAE 522310000) com e) área superior a $3.500 \mathrm{~m}^{2}$

\section{DE PISTA DUPLA/ PERMITIDO TODOS OS USOS, EXCETO:}

a) Grau de Incomodidade $\mathrm{Gl}$-3, G/-4 e G/-5;

b) atividades com áreas ocupadas superior a $540 \mathrm{~m}^{2}$.

Atividades de estacionamento (CNAE 522310000) com área superior $a$ $3.500 \mathrm{~m}^{2}$

Fonte: Elaborado pela própria autora a partir dos dados do Anexo II do Plano Diretor de Goiânia de 2007 e do Anexo I da Lei n. 8.617/08 
O artigo 116-A do Plano Diretor amplia a área de influência das vias expressas, passando a admitir a ocupação das vias sob a sua área de influência com o mesmo grau de incomodidade, porte e impacto admitidos para as primeiras (vias expressas). Isso devido à inserção da expressão "Área de Influência de Vias Expressas".

Assim, a Avenida Perimental Norte (citada no artigo 116-A), como via Expressa que é, transfere seu grau de incomodidade e a possibilidade de construção de empreendimento de impacto. Uma vez que, como visto na Tabela 4, ela não possui grau de incomodidade nem restrição à construção de empreendimento de impacto, desde que cumpridos os requisitos do artigo 95 do Plano Diretor de 2007, a Avenida Goiás, que não permitia grau de incomodidade 5 e a Avenida Eurico Viana, que não permitia grau de incomodidade 4 e 5 . Portanto, pelo novo artigo, a Avenida Goiás e a Avenida Eurico Viana passam a não possuir restrição de grau de incomodidade e nem objeções as construções de impacto.

A diferença entre o antes e o depois do artigo 116-A do Plano Diretor/2007 é observada na Figura 6:

Figura 6: Comparação das mudanças das zonas de incomodidade com a inclusão do Artigo 116-A do Plano Diretor de Goiânia/2007

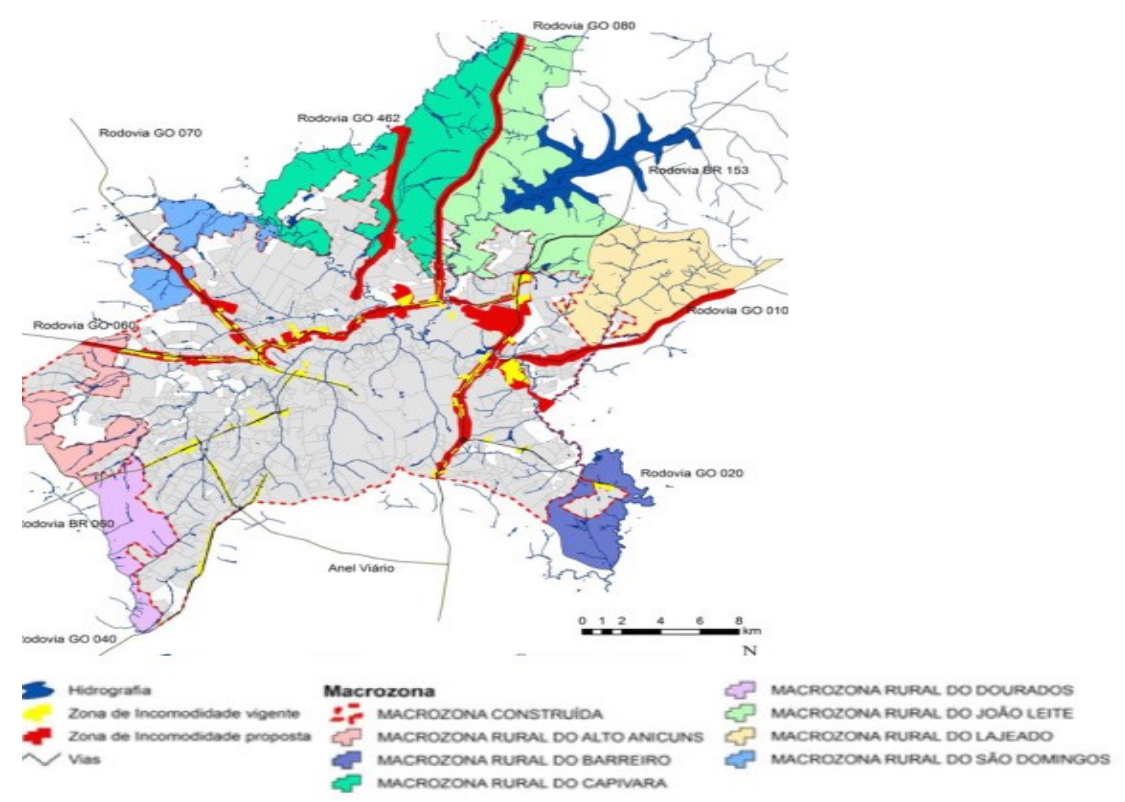

Fonte: Parecer Técnico sobre as Mudanças no Plano Diretor de Goiânia, p. 212013. 
$\mathrm{Na}$ Figura, percebe-se que as proximidades da Região Norte de Goiânia tiveram as zonas de incomodidade proposta (em vermelho na figura) ampliadas com o artigo 116-A. Isso é devido à existência da Perimentral Norte que corta grande parte da Região. O mesmo efeito é verificado nas outras vias expressas estipuladas no artigo 116-A. Observa-se que as zonas de incomodidade propostas coincidem com as zonas de hidrografia rica da Região Norte de Goiânia, nas proximidades do Rio Meia Ponte, do Córrego Caveiras e outros. Para o Parecer Técnico sobre as Mudanças no Plano Diretor de Goiânia (2013, p.22) o artigo tem que ser totalmente excluído devido aos seguintes motivos:

a) Ausência de estudos técnicos que subsidiem a presente alteração;

b) a fragilidade ambiental da área de influência do rio Meia Ponte não foi considerada (proximidades do Balneário Meia Ponte, da ETE, da saída da GO-010, dentre outras). Esse é o manancial mais importante do Estado de Goiás e, ao invés de se permitir ocupações em suas proximidades, deveriam ser propostas zonas de amortecimento, tais como parques lineares, em toda sua extensão, para se mitigar os impactos ambientais advindos das atividades antrópicas;

c) não considera os princípios da Carta de Risco da Cidade, nem os critérios ambientais (bacias hidrográficas) do macrozoneamento da cidade $e$

d) falta de precisão da Figura 20. Na escala da figura apresentada é impossível ter a real dimensão da proposta. Áreas distantes das vias expressas estão marcadas nesta mesma figura, sem nenhuma justificativa técnica, como, por exemplo, em áreas próximas ao cruzamento da Av. Perimetral Norte com o rio Meia Ponte.

Tais contornos jurídicos legitimam o avanço urbanístico, diante do interesse mercadológico de levar estruturas industriais, atacadistas, shoppings e outros empreendimentos de grande impacto para uma Região na qual os impactos socioambientais são mitigados tendo em vista as promessas de emprego e de ascensão econômica. 


\title{
4.4 ARTIGO 116-B DO PLANO DIRETOR DE GOIÂNIA DE 2007
}

\author{
É o artigo 116-B do Plano Diretor de Goiânia/2007:
}

\begin{abstract}
Art. 116-B - Nas vias locais 3,4 e 5, localizadas nas Unidades Territoriais denominadas Áreas Adensáveis e Área de Desaceleração de Densidade, serão admitidas todas as tipologias e portes de usos e atividades não residenciais GI- 1 e Gl- 2 admitidas na Lei 8617/2008, exigindo - se elaboração preliminar de Estudo de Impacto de Trânsito - EIT e de Estudo de Impacto de Vizinhança - EIV, para os casos previstos na Seção III, do Capítulo I, do Título IV, desta Lei.
\end{abstract}

Tal artigo contradiz o caput do artigo 116 da mesma Lei, uma vez que o último (o artigo 116) estipula lei específica para tratar do grau de incomodidade, que atualmente está no Decreto n. 734/2012 para o grau de incomodidade das atividades e na Lei n. 8.617/2012 para o grau de incomodidade das vias. Em contrapartida, o artigo 116-B altera o grau de incomodidade diretamente no Plano Diretor, trazendo diferentes graus de incomodidade para as vias locais 3, 4 e 5, localizadas nas Unidades Territoriais denominadas Áreas Adensáveis e Área de Desaceleração de Densidade, sendo que o que deveria ser alterado é o Anexo I da Lei n. 8.617/2012. Isso causa total insegurança jurídica, uma vez que, não se sabe qual norma deve ser respeitada.

E ainda, enquanto no Plano Diretor/2007, o artigo 116-B admite os graus de incomodidade 1 e 2 para as vias locais, não diferenciando a incomodidade entre as vias de pista únicas e duplas, o Anexo I da Lei n. 8.617/2012 (lei específica que deve tutelar a matéria segundo o caput do Artigo 116) não permite grau de incomodidade a partir de 2 para via local de pista única e a partir de 3 para via local de pista dupla, de acordo com a Tabela 2. Assim, consta-se que o Plano Diretor é mais brando que a Lei Específica n. 8.617/2012, o que beneficia o empreendedorismo urbano para a Região, já que expande o grau de incomodidade das vias locais. 


\section{A SOBREPOSIÇÃO LEGISLATIVA}

Conquanto seja nesse trabalho ressaltada a atuação especifica do Plano Diretor, não se pode vê-lo tão só como norma urbanística, uma vez que deve ser relembrada a peculiaridade dessa norma: a coesão dinâmica, já que essa (coesão dinâmica) está estabelecida dentro do próprio Plano, via instituição de instrumentos de ordem ambiental, agrária e de outras diversas matérias usadas para harmonizar as relações territoriais em âmbito dos interesses privados e coletivos.

Assim, quando uma norma que já prima pela interdisciplinaridade para ser plenamente eficaz encontra um ambiente também diverso, ou seja, de Fronteiras, como é a Região Norte e a Área N de Goiânia, a sobreposição legislativa ganha maior visibilidade e complexidade em seus pleitos.

Desse modo, a sobreposição legislativa está nas contradições legislativas surgidas em função de normas dissociadas, dentro do próprio Plano e para além dele, que violam outras normas ou que assumem competências descabidas ou que permitem várias interpretações ou que é originária de uma lei extemporânea e mais outros "ous".

Desde a aprovação do Estatuto da Cidade, a lei federal tem sido complementada por uma longa série de outras leis federais: Medida Provisória n. 2.220/2001 (Concessão de Uso Especial para Fins de Moradia); n. 11.079/2004 (Parcerias Público-Privadas); n. 10.931/2004 (Crédito e Registro Imobiliário); n. 11.107/2005 (Consórcios Públicos); n. 11.124/2005 (lei de iniciativa popular que criou o Fundo Nacional de Habitação de Interesse Social FNHIS); n. 11.445/2007 (Política de Saneamento); n. 11.481/2007 (Terras da União); n. 11.888/2008 (Assistência Técnica para Comunidades); n. 11.977/2009 (que criou o Programa Minha Casa Minha Vida - PMCMV e dispôs sobre regularização fundiária); n. 11.952/2009 (Amazônia Legal); n. 12.305/2010 (Política de Resíduos Sólidos); as mais recentes, sendo a Lei Federal $n$. 12.608/2012 (Política Nacional de Defesa e Proteção Civil) e a Lei Federal n. 13.089/2015 (Estatuto da Metrópole).

Todas essas são direta ou indiretamente leis urbanísticas aprovadas na esfera federal, sem falar das diversas convenções e tratados internacionais que o Brasil tem assinado e ratificado 
(especialmente sobre direitos de moradia); nas incontáveis leis ambientais e sobre patrimônio cultural, desapropriação e registro imobiliário aprovados também na esfera federal; nos projetos de leis em discussão (especialmente PL n. 3.057/2000, que trata o parcelamento do solo urbano e dos condomínios urbanísticos); nos anteprojetos (especialmente o que dispõe sobre resolução de conflitos fundiários); bem como nos igualmente incontáveis decretos, Resoluções do Conselho Nacional das Cidades, resoluções do CONAMA e instruções normativas da Caixa Econômica Federal (FERNANDES, 2016, p.24 grifo da autora).

Sob esse contexto OST observa que (1995, p.124-125):

[...] citando Baudrillard, S. Charbonneau "o consumo dos textos é, na nossa sociedade, idêntico ao consumo dos objetos". De onde resulta a insegurança jurídica, bem como uma aplicação cada vez mais "instrumental" de regras que surgem, pelo menos aos olhos dos atores melhor informados, como um conjunto de "recursos" que se prestam a uma utilização oportunista em função do resultado procurado.

Paradoxalmente, o "pan-juridicismo", ou invasão de um campo determinado por uma acumulação de regras em modificação permanente conduz então ao "não direito", em que alguns atores dispõem do poder unilateral de aplicar ou não os textos, ou de escolher o que melhor Ihes convier em função das circunstâncias.

[...] ora quanto mais um texto comporta exceções e possibilidades de derrogação maior é o poder discricionário concedido à administração encarregada de assegurar a sua aplicação, e mais delicado o controle da legalidade exercida pelo juiz a respeito da prática administrativa. Ora, uma administração que disponha de um amplo campo de manobra é uma administração frágil, desprovida de proteções relativamente às inevitáveis pressões que exercerão sobre ela os interesses econômicos dominantes.

Nessa conjuntura de sobreposição legislativa, a norma legaliza uma atuação presente, já que muitos empreendimentos, moradias 
e corporações já se concretizaram na Região, ao mesmo tempo em que também incentiva uma expansão futura, pois muito pressionado, principalmente, pela especulação imobiliária que atualmente ocorre na Região Norte, o Plano Diretor tende a ensejar as perspectivas público-privadas na busca do desenvolvimentismo e dos interesses individuais e isso reflete na aplicação das normas e na disposição da região de Fronteiras.

\section{CONCLUSÃO}

Com as alterações feitas no Plano Diretor de Goiânia/2007 pela Lei Complementar n. 246/2013, a cidade de Goiânia passa por um novo direcionamento de crescimento: rumo à parte Norte do Município.

O papel legislativo no amadurecer dessa nova Região Norte goianiense é significativo, já que, pela Lei Complementar n. 246/2013, foram feitas alterações/inclusões de quatro artigos do Plano Diretor/2007: os artigos 110-A, 116-A, 116-B e o artigo 110 que considera a Região Norte como de Adensamento Básico.

Do estudo de todos esses artigos foi visualizada a influência da lei na autorização/legalização para o direcionamento do "desenvolvimento" da Região, mesmo que tal Lei Complementar seja inconstitucional, que contradiga o próprio Plano Diretor, o Estatuto da Cidade e as Cartas de Risco.

Devido a essas contradições, tramitou no judiciário goiano Ação Civil Pública ${ }^{17}$ contra o Plano Diretor de Goiânia que fez as alterações dos referidos artigos estudados àquela época. Contudo, ainda no ínterim processual dessa Ação Civil Pública ${ }^{18}$, foi passado tanto tempo que o Plano Diretor/2007 já está novamente em fase de revisão.

17 Sobre explicação da Ação Civil Pública, veja matéria do site do Ministério Público do Estado de Goiás no link <http://www.mpgo.mp.br/portal/noticia/promotora-esclarecesobre-decisao-do-tribunal-de-justica-em-relacao-ao-plano-diretor-de-goiania\#. XNXQDkqJLIU>.

18 Atual acompanhamento do tramite processual da Ação Civil Pública <https://pjd.tjgo.jus. br/BuscaProcessoPublica?PaginaAtual $=2 \& P a s s o=7>$. 
Nesta conjuntura, a cidade se constitui num produto a ser vendido e, aos poucos, deixa de ser o espaço das políticas públicas, do meio ambiente equilibrado e da construção de cidadania. Tendo em vista todo o exposto, questões como o trânsito, meio ambiente, paisagem urbanística e segregação espacial dos moradores de baixa renda são deixadas de lado.

\section{REFERÊNCIAS BIBLIOGÁFICAS}

ABIKO, Alex Kenya; ALMEIDA, Marco Antonio Placido de; BARREIROS, Mário Antônio Ferreira. Urbanismo: História e desenvolvimento. 1995. Disponível em <www.pcc.usp.br/files/text/publications/ TT_00016.pdf>. Acessado em: 18 de maio de 2016.

AMADO, Frederico Augusto Di Trindade. Direito Ambiental Esquematizado. 5. Ed. São Paulo: Método, 2014.

ARAÚJO, Flavio Faria de; PFEIFFER, Cláudia Ribeiro. Empresariamento Urbano: concepção, estratégias e críticas. Code 2011. Anais do I Circuito de debates acadêmicos. Disponível em <http://www.ipea.gov.br/code2011/chamada2011/pdf/area7/area7artigo7.pdf.>. Acessado em: 18 de maio de 2016.

BRASIL. Constituição da República Federativa do Brasil. $18^{\mathrm{a}}$ Ed. São Paulo: SARAIVA, 2016.

BRASIL. CONAMA. Resolução n. 1, de 23 de janeiro de 1986. Disponível em <www.mma.gov.br/port/conama/res/res86/res0186. html>. Acessado em: 10 de abril de 2016.

BRASIL. CONAMA. Resolução n. 369, de 28 de março de 2006. Disponível em www.mma.gov.br/port/conama/legiabre. cfm?codlegi=489. Acessado em: 10 de abril de 2016.

BRASIL. CONAMA. Resolução n. 237, d 19 de dezembro de 1997. Disponível em <www.mma.gov.br/port/conama/res/res97/res23797. html>. Acessado em: 10 de abril de 2016. 
BRASIL. Estatuto da Cidade. $3^{a}$ Ed. Brasília: Senado Federal, Subsecretaria de Edições Técnicas, 2008.102 p. Disponível em <https:// www2.senado.leg.br/bdsf/bitstream/handle/id/70317/000070317. pdf?sequence=6.>. Acessado em: 2 de janeiro de 2016 .

BRASIL. Lei n. Lei n. 12.651/2012 - Novo Código Florestal. Disponível em <www.planalto.gov.br/ccivil_03/_ato2011-2014/2012/lei/ 112651.htm>. Acessada em: 2 de janeiro de 2016.

BRASIL. Projeto do II Plano Nacional de Desenvolvimento - II PND (1975-1979). Brasília, DF: Senado, 1974.

FERNANDES, Édésio. Estatuto da Cidade, 15 anos depois: razão de descrença ou razão de otimismo? In: Revista Brasileira de Direito Urbanistico- RBDU. - ano 2, n. 2, (jan./jul. 2016) - Belo Horizonte: Fórum, 2016.

. Estatuto da Cidade: razão de descrença ou de otimismo? Adicionando complexidades à reflexão sobre a efetividade da lei. In FDUA- Fundação de Direito Urbano e Ambiental 47, set-out./2009. <http://bdjur.stj.jus.br/dspace/handle/2011/29672>. Acessado em: 10 de fevereiro de 2016.

GOIÂNIA. Código de Obras- Lei Complementar n. 177 de 09 de janeiro de 2008. Disponível em <www.goiania.go.gov.br/download/ legislacao/codigodeobras.pdf $>$. Acessado em: 22 de maio de 2016.

GOIÂNIA. Decreto n. 734/2012. Disponível em <https://www. goiania.go.gov.br/html/gabinete_civil/sileg/dados/legis/2012/ dc_20120328_000000734.pdf.>. Acessado em 22 de maio de 2016.

GOIÂNIA. Inquérito Civil Público n. 201300350557. Disponível no Ministério Público do Estado de Goiás. $8^{a}$ Promotoria e Meio Ambiente e Urbanismo.

GOIÂNIA. Lei Complementar n. 181/2008. Disponível em <https:// www.goiania.go.gov.br/Download/seplam/Colet\%C3\%A2nea\%20 Urban\%C3\%ADstica/10.\%20Vazios\%20Urbanos/10.\%20Vazios $\% 20$ 
Urbanos\%20-\%20Lei\%20181.pdf.>. Acessado em: 22 de maio de 2016.

GOIÂNIA.LeiComplementarn.8646, de23deJulhode2008.Disponível em <https://www.goiania.go.gov.br/html/../lo_20080723_000008646. pdf $>$. Acessado em 22 de maio de 2016.

GOIÂNIA. Lei Orgânica do Município de Goiânia. $5^{\mathrm{a}}$ ed. Goiânia: Câmara Municipal, 2012. 105 p. Disponível em <https://www.goiania. go.gov.br/.../lei_organica_municipio_goiania.pdf>. Acessado em: 2 de janeiro de 2016.

GOIÂNIA. Plano Diretor- Lei 171, de 29 de junho de 2007. Disponível em <https://www.goiania.go.gov.br/...\%20Plano\%20Diretor/1.\%20Plano\%20.>. Acessado em: 2 de janeiro de 2016.

GUSTIN, Miracy Barbosa de Sousa; DIAS, Maria Tereza Fonseca. (Re)pensando a pesquisa jurídica: teoria e prática. Belo Horizonte: Del Rey, 2006.

MARICATO, Ermínia. Metrópole, legislação e desigualdade. In: Estudos Avançados, 2003. Disponível em <http://www.scielo.br/pdf/ ea/v17n48/v17n48a13.pdf.>. Acessado em: 5 de agosto de 2016.

MARQUES, Benedito Ferreira. Direito Agrário Brasileiro. $11^{a}$ Edição. São Paulo: Atlas, 2013.

NASCIMENTO, Diego Tarley Ferreira; OLIVEIRA, Ivanilton José de. Mapeamento do processo histórico de expansão urbana do município de Goiania-GO. GEOgraphia - Ano. 17 - No $34-2015$. Disponível em <http://www.uff.br/geographia/ojs/index.php/geographia/ article/download/619/567.> Acessado em: 10 de fevereiro de 2016.

NASCIMENTO, M. A. L. S; PODESTÁ FILHO, A. de. Carta de Risco de Goiânia (1993). Boletim Goiano de Geografia, n. 1, v. 13.

OLIVEIRA, Adão Francisco de. Metrópoles e metropolização no Brasil: o caso de Goiânia Sociedade e Cultura. Vol. 16, núm. 1, janeiro-junho, 2013, pp. 153-167. Universidade Federal de Goiás 
- Goiânia, Brasil. Disponível em <www.revistas.ufg.br/fchf/article/ view/28218>. Acessado em: 10 de fevereiro de 2016.

PASQUALETTO, Antônio, et al. Shopping Passeio das Águas: Análise do estudo de Impacto de Vizinhança e o sentimento dos moradores. In: BVRU, Goiânia, v. 1, n. 1, p. 81-95, jul./ dez. 2015. Disponível em <seer.ucg.br/index.php/baru/article/ download/4464/2580>. Acessado em: 21 de setembro de 2016.

PASQUALETTO, Antônio; RODOVALHO, Márcia. Eficácia e efetividade no Plano Diretor de Goiânia. In: Estudos.Goiânia, v. 39, n. 1, p. 45-60, jan./mar. 2012. Disponível em <http://seer.ucg.br/index. php/estudos/article/view/2364>. Acessado em: 8 de julho de 2016.

SANTOS, Akiko. O que é transdisciplinariedade. In: Rural Semanal, da Universidade Federal Rural do Rio de Janeiro, I parte: na semana de 22/28 de agosto de 2005; II parte: na semana de 29/04 de setembro de 2005. Disponível em <www.ufrri.br/leptrans/.../O_QUE_e_ TRANSDISCIPLINARIDADE.pdf.> Acessado em: 10 de agosto de 2016.

SANTOS, Milton. A natureza do espaço: Técnica e tempo, razão e emoção. 4. Ed. São Paulo: Editora da Universidade de São Paulo, 2006.

A urbanização brasileira. 5. Ed., São Paulo: Editora da Universidade de São Paulo, 2013.

Por uma Geografia Nova: Da crítica da geografia a uma geografia crítica. 6 . Ed., São Paulo: Editora da Universidade de São Paulo, 2004.

Metamorfoses do espaço habitado. São Paulo: Hucitec,

1988.

O retorno do território. In: OSAL: Observatório Social de América Latina. Año 6 no. 16 (jun.2005- ). Buenos Aires: CLACSO, 2005. ISSN 1515-3282. Disponível em <http:// bibliotecavirtual.clacso.org.ar/ar/libros/osal/osal16/D16Santos.pdf>. Acessado em: 06 de julho de 2016. 
SEPLAN-GO / SEPIN / Gerência de Estatísticas Socioeconômicas. Bacias Hidrográfica do Estado de Goiás. 2003. Disponível em <http://www.seplan.go.gov.br/sepin/pub/anuario/2003/images/mapa2. jpg.> Acessada em: 10 de fevereiro de 2016.

SILVA, José Afonso da. Direito Ambiental Constitucional. 4. Ed. São Paulo: Malheiros, 2003.

Malheiros, 2015.

Direito Urbanístico Brasileiro. $7^{a}$ Ed. São Paulo:

TAVARES, Altair. O Plano Diretor de Goiânia: prefeitura tenta explicar para anular confusões. Jornal Diário de Goiás. Goiânia, GO. 01/05/2013. Disponível em <http://diariodegoias.com.br/ cidades/2133-plano-diretor-de-goiania-prefeitura-tenta-explicar-eanular-confusoes> Acessado em: 18 de janeiro de 2016. 